\title{
Article \\ Synthesis of MnO/C/NiO-Doped Porous Multiphasic Composites for Lithium-Ion Batteries by Biomineralized Mn Oxides from Engineered Pseudomonas putida Cells
}

\author{
Jin Liu, Tong Gu, Li Li and Lin Li * (1)
}

check for updates

Citation: Liu, J.; Gu, T.; Li, L.; Li, L. Synthesis of $\mathrm{MnO} / \mathrm{C} / \mathrm{NiO}-$ Doped Porous Multiphasic Composites for Lithium-Ion Batteries by Biomineralized Mn Oxides from Engineered Pseudomonas putida Cells. Nanomaterials 2021, 11, 361. https: / / doi.org/10.3390/ nano11020361

Received: 5 January 2021

Accepted: 28 January 2021

Published: 1 February 2021

Publisher's Note: MDPI stays neutral with regard to jurisdictional claims in published maps and institutional affiliations.

Copyright: (c) 2021 by the authors. Licensee MDPI, Basel, Switzerland. This article is an open access article distributed under the terms and conditions of the Creative Commons Attribution (CC BY) license (https:/ / creativecommons.org/licenses/by/ $4.0 /)$.
State Key Laboratory of Agricultural Microbiology, Huazhong Agricultural University, Wuhan 430070, China; liujinlj1987@163.com (J.L.); gutong1117@webmail.hzau.edu.cn (T.G.); lily999wy@126.com (L.L.)

* Correspondence: lilin@mail.hzau.edu.cn; Tel.: +86-27-87286952; Fax: +86-27-87280670

\begin{abstract}
A biotemplated cation-incoporating method based on bacterial cell-surface display technology and biogenic Mn oxide mineralization process was developed to fabricate Mn-based multiphasic composites as anodes for Li-ion batteries. The engineered Pseudomonas putida MB285 cells with surface-immobilized multicopper oxidase serve as nucleation centers in the Mn oxide biomineralization process, and the Mn oxides act as a settler for incorporating Ni ions to form aggregates in this process. The assays using $\mathrm{X}$-ray photoelectron spectroscopy, phase compositions, and fine structures verified that the resulting material $\mathrm{MnO} / \mathrm{C} / \mathrm{NiO}(\mathrm{CMB}-\mathrm{Ni})$ was porous multiphasic composites with spherical and porous nanostructures. The electrochemical properties of materials were improved in the presence of $\mathrm{NiO}$. The reversible discharge capacity of CMB-Ni remained at $352.92 \mathrm{mAh} \mathrm{g}^{-1}$ after 200 cycles at $0.1 \mathrm{~A} \mathrm{~g}^{-1}$ current density. In particular, the coulombic efficiency was approximately $100 \%$ after the second cycle for CMB-Ni.
\end{abstract}

Keywords: biogenic manganese oxides; lithium-ion battery; biotemplate; bacterial cell surface display; hollow porous biocomposite

\section{Introduction}

The electrochemical performance of lithium-ion batteries depends largely on the properties of the electrode materials. There have been many reports on materials with high lithium storage capacity, including transition metal oxides and metalloids, such as $\mathrm{NiO}$, $\mathrm{Co}_{3} \mathrm{O}_{4}$, and $\mathrm{ZnO}$ [1-3]. Among the various available transition metal oxides, $\mathrm{MnO}$ has attracted significant attention due to its low cost, high theoretical capacity $\left(756 \mathrm{mAh} \mathrm{g}^{-1}\right)$, and relatively low running potential $\left(1.032 \mathrm{~V}\right.$ vs. $\left.\mathrm{Li} / \mathrm{Li}^{+}\right)[1,4,5]$. However, despite the promising electrochemical properties of $\mathrm{MnO}$, its application as an electrode material is generally limited by poor rate discharge performance and short cycle life, which is caused by severe particle aggregation and a huge volume change in the charging-discharging process [6].

Two technical routes are presumable to solve this problem. The first route is to incorporate with other elements, particularly metal ions [7,8], nitrogen and oxides [9], to improve the stability of the crystal structure and to enhance the electrical contact between oxide particles, as well as between oxide particles and the current collector, as demonstrated by $\mathrm{Li}$ et al. who prepared Fe-Mn-O composites with different Fe/Mn ratios by a simple coprecipitation process. The resultant composites showed better electrochemical properties than those of single $\mathrm{Fe}_{3} \mathrm{O}_{4}$ or $\mathrm{MnO}$ electrode materials [10]. The second route for improving the electrode performance of $\mathrm{MnO}$ is to fabricate biocomposites with distinctive morphologies, such as microspheric, hollow, porous, and nuclear shell structures, which can enhance the contact between electrolyte and internal active substances to accelerate the transfer of $\mathrm{Li}^{+}$. Among the various available approaches for this purpose, the biotemplate and surface display technologies have increasing appeal due to the effectiveness, regeneration, 
and good performance of the methods available that allow the fabricated materials to be endowed with the complicated fine structures and functional characteristics of template organisms, as validated by several previously developed virus surface display systems, such as in phage M13 and other filamentous bacteriophages [11,12]. However, while the feasibility of combining the phage surface display technology and biotemplate method has been intensively investigated, there are still only a few studies on the application of other microbial surface display technologies that integrate a biotemplate process.

The key to biomineralization is to realize the ordered sedimentation, growth, and assembly of metal oxides under the regulation and control of organic matter. With the revelation of the mineralization mechanism, the mineralization reconstruction of specific functional organisms via generation of functional inorganic shells or crystals by biomineralization has shown potential for the fabrication of metal oxide materials. Previous research demonstrated that the surface display of $\mathrm{Mn}$ oxidases on bacterial cells can retain their biological activity by fusion of an activity-independent amino acid to a cell wall-binding anchor protein, which further enables fast and goal-oriented Mn oxidation reaction and formation of Mn oxide deposit layers on cell surface [13]. Due to the non-uniformity of Mn valence states and the presence of lattice vacancies in biogenic Mn oxides, additional cations were required to compensate the negative charge. Moreover, biogenic Mn oxides have the characteristics of settlers for metal ions, the additional metal ions, such as $\mathrm{Co}^{2+}, \mathrm{Ni}^{2+}, \mathrm{Zn}^{2+}$, and $\mathrm{Pb}^{2+}$, could be utilized as mineral components through a redox reaction in the crystal growth process of Mn oxides [14-16]. This characteristic suggested a kind of technical route to realize facile fabrication of multi-metal mineral materials under mild conditions. The minerals were released in a way that the Mn oxidases do not become encumbered by Mn oxides, which are less likely to associate with the enzyme [17]. The dense aggregates, consisting of Mn oxides and bacteria, could be formed by gradual sedimentation [13]. The carbonaceous organic compounds arising from bacteria could be used as biological templates to provide a fundamental structure for subsequent materials. The organic carbon also could be decomposed in high-temperature annealing to form carbon, which form a reducing atmosphere to transform $\mathrm{MnO}_{2}$ to $\mathrm{MnO}$ as well as served as a carbon matrix for Mn oxides embedding after calcination. The space formed in the decomposition process led to a special morphology with multilevel micro-nano structures of porous irregular microspheres. The Mn oxides produced in the mineralization were used as the source for $\mathrm{MnO}_{\mathrm{x}}$ after calcination.

In this study, a porous $\mathrm{MnO} / \mathrm{C} / \mathrm{NiO}$ composite $(\mathrm{CMB}-\mathrm{Ni})$ was prepared using bacterial surface display technology and a biotemplate method (Scheme 1). Pseudomonas putida MB285 is an engineered strain expressing surface-immobilized multicopper oxidase (MCO) which can catalyze the oxidization of $\mathrm{Mn}^{2+}[13,18,19]$ and gradually forming the microspherical porous aggregates with biofilm coated strains and Mn oxides. A unique incorporating method by biomineralization was designed, in which $\mathrm{Ni}^{2+}$ ions was incorporated into the crystal structure of biogenic Mn oxides under mild conditions. The aggregate precursor was subsequently carbonized at different high temperatures and carbonaceous MnO-based multiphasic nanocomposites were fabricated. The crystallization state evolution of the resultant materials was further determined. The electrochemical properties of nanocomposites as the anode materials for lithium-ion batteries were measured. The possible reasons for performance differences of the materials are discussed. 


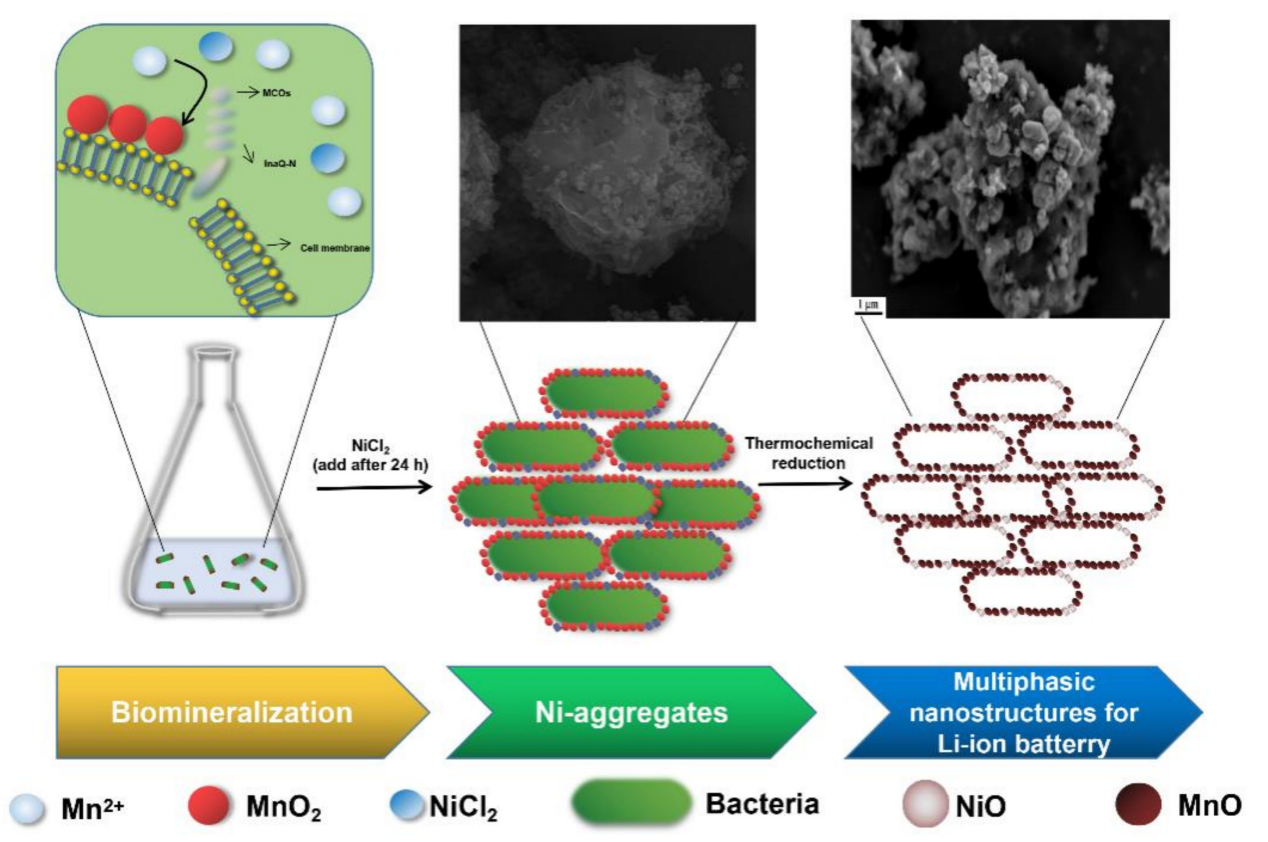

Scheme 1. Schematic illustration of the procedures used in the process of MnO-based multiphasic CMB-Ni fabrication.

\section{Materials and Methods}

\subsection{Chemicals, Bacterial Strains, Culture Conditions, and $\mathrm{Mn}^{2+}$-Oxidizing Activity Assay}

All chemicals were of analytical grade and were used as received without further purification. $\mathrm{NiCl}_{2} \cdot 6 \mathrm{H}_{2} \mathrm{O}(\geq 99 \%$ ) was purchased from Sigma-Aldrich Co. (LLC., Shanghai, China) and was used as the $\mathrm{Ni}$ ion source in the Leptothrix medium [20] for the cationincorporated composite.

A previously constructed engineered bacterial strain P. putida MB285, which expresses the recombinant "(InaQ-N $)_{3}$-WlacD", a fusion protein with three tandem repeated InaQ-N anchors and a mutated bacterial laccase WlacD, was used as the host strain for the production of Mn oxide aggregates under laboratory shaker-flask trials [18]. The strain was routinely grown in liquid Leptothrix medium supplemented by $1 \mathrm{mM} \mathrm{MnCl}_{2}$ at $28^{\circ} \mathrm{C}$ at a shaking of $150 \mathrm{rpm}$. The $\mathrm{Mn}^{2+}$-oxidizing activity was measured over a time course of $15 \mathrm{~d}$. A standard leucoberbelin blue (LBB) spectrophotometry assay was performed for $\mathrm{Mn}$ oxide quantification, as previously described [21].

\subsection{Preparation of $\mathrm{MnO} / \mathrm{C} / \mathrm{NiOComposite}$}

The preparation and use flow of the $\mathrm{MnO} / \mathrm{C} / \mathrm{NiO}$ porous composite is illustrated in Scheme 1. Firstly, for the preparation of Mn oxide aggregates, the suspension cultures were harvested after cultivating P. putida MB285 cells for $12 \mathrm{~d}$. The yielded biogenic $\mathrm{MnO}_{2} /$ bacteria composites (BMB) were rinsed three times with double distilled water and then dried at $80{ }^{\circ} \mathrm{C}$ for $10 \mathrm{~h}$. The biogenic $\mathrm{MnO}_{2} /$ bacteria Ni-incorporated aggregates (BMB-Ni) were prepared in parallel, except that $\mathrm{NiCl}_{2}$ was added to the culture at a final concentration of $1 \mathrm{mM} 24 \mathrm{~h}$ after the strain was inoculated. Secondly, for the thermochemical process, the $\mathrm{MnO} / \mathrm{C}$ composite was obtained by calcination of the $\mathrm{BMB}$ in a tube furnace at $800^{\circ} \mathrm{C}$ (temperatures in the range of $400-800{ }^{\circ} \mathrm{C}$ were investigated, the corresponding materials were defined as B400, B600 and B800, respectively) for $4 \mathrm{~h}$ with a ramp of $5^{\circ} \mathrm{C} \mathrm{min}^{-1}$ under a $\mathrm{Ar}$ atmosphere. The $\mathrm{MnO} / \mathrm{C} / \mathrm{NiO}$ composite (CMB-Ni) was prepared by calcination of $\mathrm{BMB}-\mathrm{Ni}$ in a tube furnace at $800^{\circ} \mathrm{C}$.

\subsection{Material Characterization}

The phase purity and properties of the samples were measured using X-ray powder diffraction (XRD, Bruker D8 Advance diffractometer with $\mathrm{Cu} \mathrm{K} \alpha$ radiation, Bruker, 
Karlsruhe, Germany) and X-ray photoelectron spectroscopy (XPS, Multilab 2000, Thermo Electron Corporation, London, UK) with monochromatic $\mathrm{Mg} \mathrm{K} \alpha$ radiation (1253.6 eV). XPS analysis of the obtained materials was conducted on a VG Multilab2000 X-ray photoelectron spectrometer with an $\mathrm{Al} \mathrm{K \alpha}$ X-ray source $(1486 \mathrm{eV})$ and a base pressure of $3 \times 10^{-9}$ Torr in the analytical chamber [22]. The charge effect was corrected by adjusting the binding energy of adventitious C ( $1 \mathrm{~s}$ ) to $284.8 \mathrm{eV}$. The Shirley-type background was subtracted before deconvolution and data fitting using the parameters used by Nesbitt et al. [23]. For the multiplet peaks of $\mathrm{Mn}\left(2 \mathrm{p}_{3 / 2}\right)$ for spectral fitting, a 20:80 ratio of the Lorentzian-Gaussian mix-sum function was used for all data fittings [24]. Scanning electron microscopy (SEM, Hitachi S-4700) and high-resolution transmission electron microscopy (HRTEM, JEM-2100F) equipped with an energy-dispersive spectroscopy (EDS) detector were used to investigate the microstructure of the sample and analyze its elements, the HRTEM was operated at an acceleration voltage of $200 \mathrm{kV}$. The surface functional groups were analyzed by a Fourier transform infrared spectrometer (FT-IR, VERTEX 70, Bruker, Karlsruhe, Germany). Thermogravimetric analysis (TGA, thermal analysis system, TG 209, Netzsch, Bavaria, Germany) was carried out in a $\mathrm{N}_{2}$ atmosphere from room temperature (RT) to $800^{\circ} \mathrm{C}$ at a heating temperature speed of approximately $10^{\circ} \mathrm{C} \mathrm{min}{ }^{-1}$. Raman spectra were obtained on a Renishaw InVia Raman spectrometer under a backscattering geometry $(\lambda=532 \mathrm{~nm})$. Nitrogen adsorption-desorption was determined by Brunauer-Emmett-Teller (BET) tests using a Quantachrome Autosorb-1, JEDL-6390/LV, (JEOL, Tokyo, Japan).

\subsection{Assays of Electrochemical Properties}

The electrochemical performance of materials was assayed using 2016 coin-type cells with lithium as the counter electrode at RT. The working electrode was fabricated by mixing the active material, acetylene black, and a polyvinylidene fluoride binder in a weight ratio of 8:1:1. Each $1 \mathrm{M} \mathrm{LiPF}_{6}$ in the ethylene carbonate-dimethyl carbonate (1:1 by volume) was used as the electrolyte of the coin cells, which were assembled in an argon-filled glove box with a microporous membrane (Celgard 2300) as a separator. The cells were galvanostatically cycled at various current densities and the charge/discharge capacity was performed in a fixed voltage window of 0.01 to $3.0 \mathrm{~V}$ versus $\mathrm{Li} / \mathrm{Li}^{+}$using a battery tester (CT2001A Land Battery Testing System, Wuhan, China). Cyclic voltammogram (CV) tests of the electrode were carried out by a CHI 660c electrochemical workstation (Chenhua, Shanghai, China) with a scan rate of $0.1 \mathrm{mV} \mathrm{s}^{-1}$ between $0.01-3 \mathrm{~V}$.

\section{Results and Discussion}

\subsection{Formation and Characterization of BMB-Ni Aggregates}

Previous investigations have revealed that the MCOs of a variety of $\mathrm{Mn}^{2+}$-oxidizing bacteria were directly involved in $\mathrm{Mn}^{2+}$ oxidation of host cells $[25,26]$. These MCOmediated oxidation reactions all appear to be related to the cell surface $[13,27]$. To investigate the $\mathrm{Mn}^{2+}$-oxidizing activity of the engineered P. putida MB285 cells expressing surface-immobilized MCOs, a continuous $\mathrm{Mn}^{2+}$-rich culture under laboratory shake-flask conditions was conducted. The $\mathrm{Mn}^{2+}$-oxidizing activity was observed and gradually increased (Figure 1a) after cultivating P. putida MB285 cells for $7 \mathrm{~d}$. The aggregation of cells started after $12 \mathrm{~d}$ and microspherical aggregates were gradually formed (Figure $1 \mathrm{~b}, \mathrm{c}$ ). The aggregates were irregular spherical secondary particles composed of flaky Mn oxides adhered on bacteria surfaces and dispersed spherical Mn oxides. It is worth mentioning that the aggregate structure was dense and could still maintained its morphology intact at a SEM operated voltage of $200 \mathrm{kv}$, which was consistent with that finding in other studies [13]. The aggregate had a relatively uniform size with a diameter of 20-30 $\mu \mathrm{m}$ (Figure $1 \mathrm{~b}$ ). Interestingly, the $\mathrm{Mn}^{2+}$-oxidizing activity of mixed bacterial suspension increased significantly after adding $\mathrm{Ni}^{2+}$ (BMB-Ni), compared to that of net P. putida cells (BMB). Previous reports had found that LBB could also react with Co (III) oxides, so similar reactions may occur between oxidized $\mathrm{Ni}$ and $\mathrm{LBB}$, which then increased the value of the determined oxides [15]. 

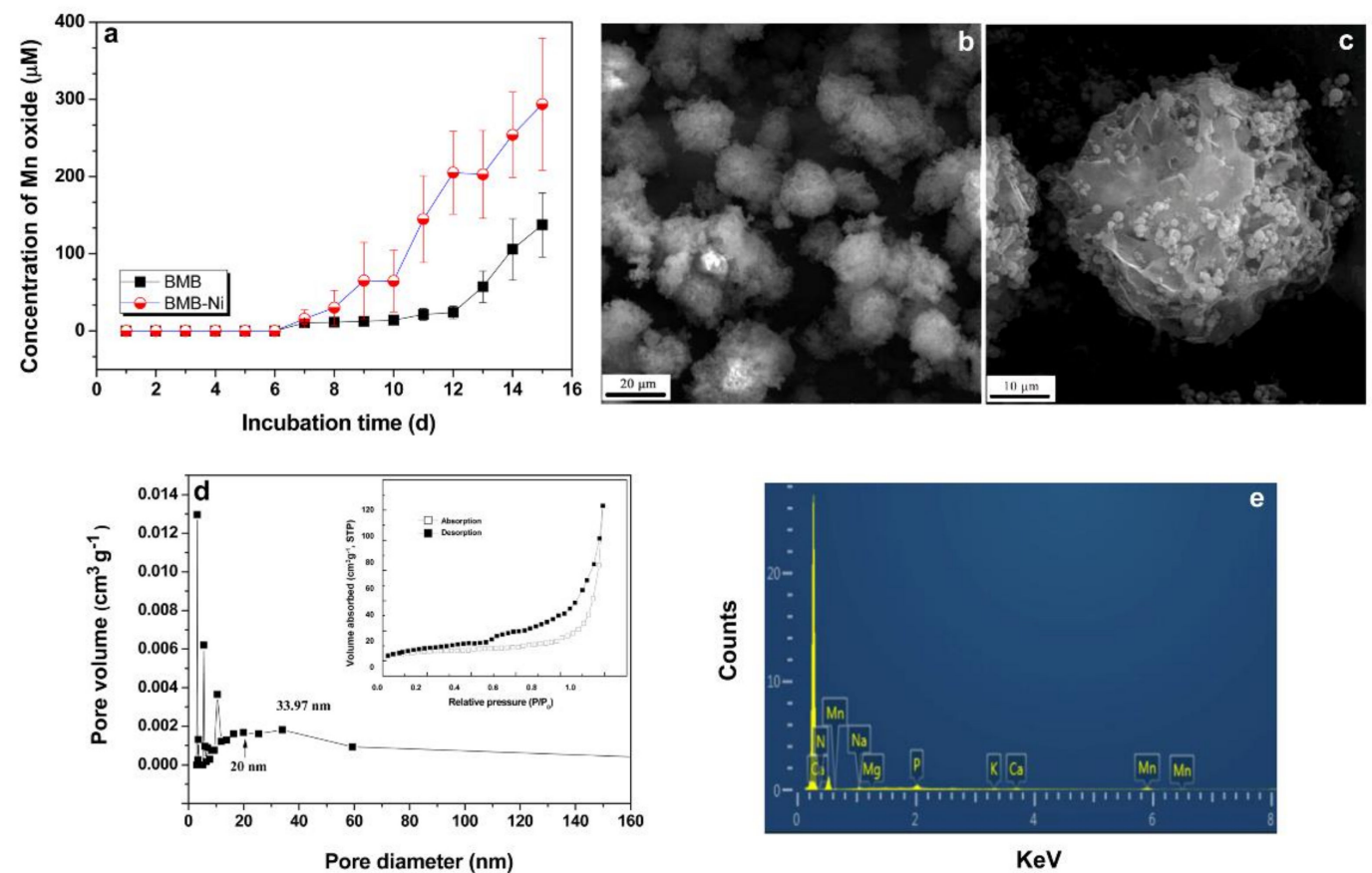

Figure 1. (a) $\mathrm{Mn}^{2+}$-oxidizing activities of BMB and BMB-Ni. (b,c) SEM images of BMB. (d) Pore size distribution curve of $\mathrm{BMB}$ calculated from the adsorption branch by the $\mathrm{BJH}$ model. The inset is the nitrogen adsorption-desorption isotherm loop. (e) Corresponding results of the line-scan SEM-EDS analysis of BMB.

There were porous structures on the surface of the microspherical aggregates. The analysis of the BET specific area and porosity (Figure 1d) indicated that the specific surface area of BMB was $20.935 \mathrm{~m}^{2} \mathrm{~g}^{-1}$. The-Barrett-Joyner-Halenda (BJH) pore size was mainly distributed at 20 and $33.97 \mathrm{~nm}$, which is classed as a mesoporous material $(0-50 \mathrm{~nm})$. The adsorption-desorption isotherm loop was H3-type (inset in Figure 1d). Usually, the H3-type material contained flaky particulate filled polymers to form a slit structure [28], consistent with the SEM observation results. According to the composition of the surface element in aggregates analyzed by line-scan EDS (Figure 1e), the content of Mn was 7.78\%, which was uniformly distributed on the microsphere surface. Meanwhile, the contents of $\mathrm{N}$ and $\mathrm{O}$ were $19.28 \%$ and $63.99 \%$ (Table S1), respectively. This indicated that the main components in aggregates were organic biomass, consistent with the results of TGA (Figure S1). After heating under an Ar atmosphere, the mass loss of $8.9 \%$ below $100{ }^{\circ} \mathrm{C}$ was due to the volatilization of the attached water on the surface. The organic carbon could be decomposed in high-temperature annealing to form carbon, which forms a reducing atmosphere, so the mass loss of aggregates reached $59.9 \%$ when the temperature was varied from 100 to $800{ }^{\circ} \mathrm{C}$, which was caused by the decomposition of organic matter and the reduction of $\mathrm{MnO}_{2}$ to $\mathrm{MnO}$ by a reducing atmosphere. Therefore, the content of organic matter from bacteria in BMB was 59.9\%.

HRTEM was performed to further investigate the microstructure of BMB. As shown in Figure 2a,b, BMB had an irregular spherical structure. Many groups of Mn oxide nanocrystal particles were independently embedded in the organic matter produced by bacteria. The interplanar spacings of 0.279 and $0.362 \mathrm{~nm}$ corresponded to the $d$ value of the (004) face of $\mathrm{Na}_{0.7} \mathrm{MnO}_{2}$ and the (012) face of $\mathrm{MnCO}_{3}$, respectively. The XRD analysis indicated that $\mathrm{BMB}$ was composed of four phases, i.e., $\mathrm{Na}_{0.7} \mathrm{MnO}_{2}$ (JCPDS card no. 270752), $\mathrm{MnCO}_{3}$ (JCPDS card no. 85-1109), $\mathrm{CaCO}_{3}$ (JCPDS card no. 17-0763) and $\mathrm{Na}_{2} \mathrm{~S}_{2} \mathrm{O}_{4}$ (JCPDS card no. 72-1157) (Figure 2c). The diffraction peaks in the spectra were attributed to the (002), (004), (112), (023), (114) and (134) planes of $\mathrm{Na}_{0.7} \mathrm{MnO}_{2}$, the (012), (104), (110), (202), (024) and (116) planes of $\mathrm{MnCO}_{3},(220)$, (212) and (520) planes of $\mathrm{CaCO}_{3}$, and the $(100),(-111),(020),(-323)$ and $(-242)$ planes of $\mathrm{Na}_{2} \mathrm{~S}_{2} \mathrm{O}_{4}$, respectively. The relatively weak strength of the diffraction peaks was caused by the high background of bioorganic matter 
in BMB. The presence of $\mathrm{Na}_{2} \mathrm{~S}_{2} \mathrm{O}_{4}$ in four phases should be related to the S-containing components in the culture medium. Both $\mathrm{Na}_{0.7} \mathrm{MnO}_{2}$ and $\mathrm{MnCO}_{3}$ were from the $\mathrm{Mn}$ oxidation of BMB. The oxidation reaction from $\mathrm{Mn}^{2+}$ to $\mathrm{Mn}^{4+}$ actuated by MCO mainly produced $\mathrm{Na}_{0.7} \mathrm{MnO}_{2}$, while $\mathrm{MnCO}_{3}$ was the by-product under anaerobic conditions in continuous culture process due to the partial lack of oxygen $[29,30]$.

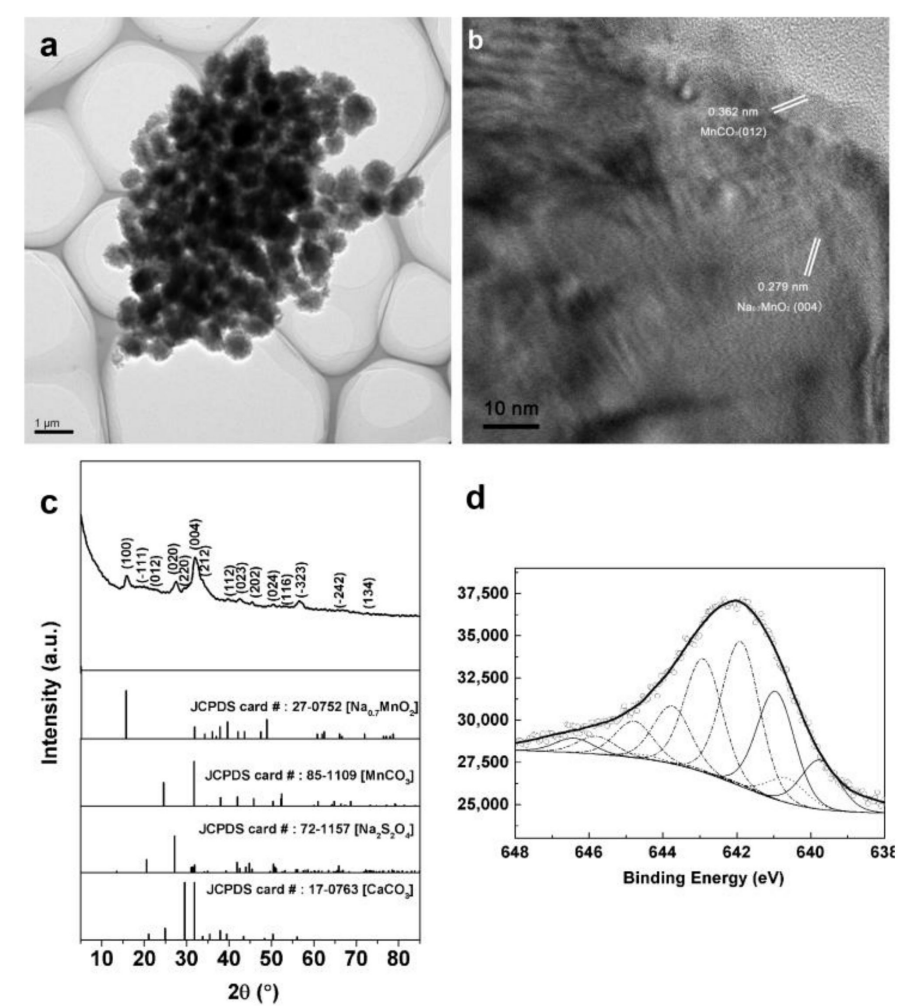

Figure 2. (a) TEM images of BMB. (b) Typical HRTEM image of BMB and measured lattice spacings of the crystals. (c) XRD patterns of BMB. (d) XPS patterns of the Mn $\left(2 \mathrm{p}_{3 / 2}\right)$ spectrogram of the Mn oxides in BMB. The upper circles represent the observed data. The thick, solid curve indicates the best fit of the data. The dashed-dotted curves represent the $\mathrm{Mn}^{4+}$ multiplet peaks, the dotted lines represent $\mathrm{Mn}^{3+}$, and the thin solid lines represent $\mathrm{Mn}^{2+}$.

The $\mathrm{Mn}^{3+}$ intermediate product existed in the electron transfer process of Mn oxidation. Since its oxidation was affected by the concentration of $\mathrm{Mn}, \mathrm{Mn}$ oxides with different valence states were possibly generated [31,32]. Therefore, the proportion of $\mathrm{Mn}$ species in BMB was analyzed by XPS (Figure 2d). The spectral fitting results of $\mathrm{Mn}\left(2 \mathrm{p}_{3 / 2}\right)$ spectra proved the presence of $\mathrm{Mn}^{2+}, \mathrm{Mn}^{3+}$, and $\mathrm{Mn}^{4+}$, with a proportion of $6.02,24.62 \%$, and $69.36 \%$, respectively (Table S2), indicating that the main oxidizing states of $\mathrm{Mn}$ ions were $\mathrm{Mn}^{4+}$, consistent with the XRD results. The FT-IR analysis showed that the Mn-O bonds were not detected for pure MB285 cells or the mixture of cells and $\mathrm{MnCl}_{2}$ without cultivation. However, after Mn oxidation of MB285 to produce BMB, a new vibration peak appeared at $612 \mathrm{~cm}^{-1}$, which was assigned to the Mn-O band (Figure S2) [33]. This further proved the formation of Mn oxide after the mineralization process.

\subsection{Preparation and Characterization of $\mathrm{MnO} / \mathrm{C} / \mathrm{NiO}$ Hollow Porous Composite}

Based on their mesoporous morphology and the feasibility of natural incorporate of metal ions in the Mn mineralization process, BMB aggregates were used as a biological template to design a facile modification method for electrode materials. $\mathrm{Ni}^{2+}$ was added into MB285 culture, the $\mathrm{Ni}^{2+}$-incorporated $\mathrm{Mn}$ oxide aggregates (BMB-Ni) were harvested and were used as the precursors for high-temperature annealing $\left(800{ }^{\circ} \mathrm{C}\right)$. The organic carbons from organisms were decomposed in the annealing process and the reducing 
atmosphere was generated. Therefore, $\mathrm{MnO}_{2}$ was reduced to $\mathrm{MnO}$. Meanwhile, the residual inorganic carbon was converted into a carbon coating and electroconductive carbon matrix. The space of organic matter formed cavities and macropores after decomposition. Thus, the porous $\mathrm{MnO} / \mathrm{C} / \mathrm{NiO}$ multiphasic composites were consequentially obtained after the annealing process.

In order to investigate the influence of the calcinations temperature on the surface morphology and internal structure of the materials, $\mathrm{BMB}$ was treated at $400{ }^{\circ} \mathrm{C}, 600{ }^{\circ} \mathrm{C}$, and $800^{\circ} \mathrm{C}$. Calcinations treatments caused irregular porous particles for all materials, and the collapsed particles with a smallest volume were obviously observed for B800 (the material was treated at $800^{\circ} \mathrm{C}$ ) (Figure $3 \mathrm{a}$ and Figure S3a,c). With the increase of calcination temperature, the surface roughness of the material decreased distinctly. A significant number of attachments disappeared and the pore size gradually increased with increasing calcination temperature (Figure 3b, Figures S3b,d and S4). The shrinkage of particle volume and the decrease of surface roughness could be caused by the decomposition of organic matter in the material. The EDS analysis of B800 indicated that the contents of Mn, C and O were $28.75 \%, 9.78 \%$ and $32.2 \%$, respectively (Figure S5; Table S3). The content of Mn was 3.69 times that in BMB (Figure 1e). The TGA assay of B800 and CMB-Ni (Figure S6) revealed that the carbon content was not more than $10 \%$, which was consistent with the analysis by EDS, verifying the decomposition of organic matter at high temperatures. Figure $3 c$ showed that many particle attachments existed on the surface of the CMB-Ni, but the modified material was still morphologically similar to B800, i.e., irregularly spherical with porous structures on the surface (Figure 3d). We speculated that these particle attachments were composed of $\mathrm{Mn}$ and incorporated elements after reaction at high temperatures. The particles were analyzed by EDS linear scan assays (Figure S7). The results indicated that the main elements in particles of CMB-Ni were $\mathrm{Mn}, \mathrm{O}, \mathrm{C}, \mathrm{Ni}, \mathrm{P}$, and $\mathrm{Ca}$.
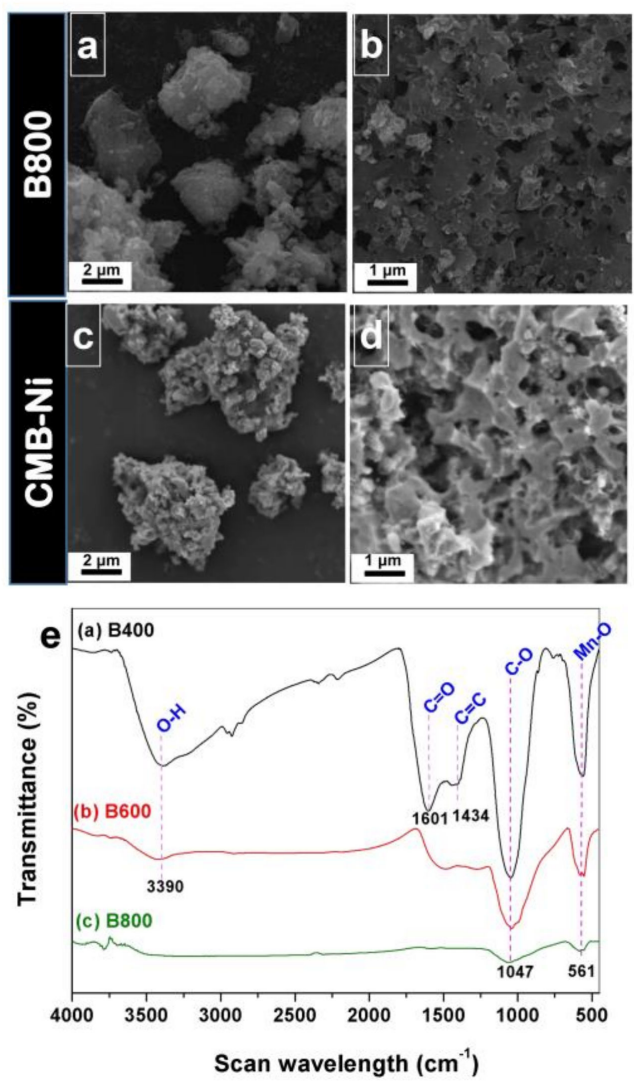

Figure 3. SEM images of (a,b) material prepared at $800{ }^{\circ} \mathrm{C}(\mathrm{B} 800)$ and (c,d) CMB-Ni. (e) Overview of FTIR of B400, B800, and B600. 
The FT-IR analysis of B400, B600 and B800 showed that all three materials had absorption peaks at 561 and $1047 \mathrm{~cm}^{-1}$, which could be attributed to the vibration peaks of Mn-O and $\mathrm{C}-\mathrm{O}$, respectively (Figure $3 \mathrm{e}$ ). This should be related to the presence of Mn oxides and carbonates in the materials. However, more vibration peaks were observed in B400 than B600 and B800, indicating the abundant chemical bonds. The peaks at 1434 and $1601 \mathrm{~cm}^{-1}$ could be attributed to the $\mathrm{C}=\mathrm{C}$ and $\mathrm{C}=\mathrm{O}$ bands, respectively. In addition, the vibration peak at $3390 \mathrm{~cm}^{-1}$, attributed to $\mathrm{O}-\mathrm{H}$, was also observed in $\mathrm{B} 400$ and $\mathrm{B} 600$. The $\mathrm{C}=\mathrm{C}, \mathrm{C}=\mathrm{O}$ and $\mathrm{O}-\mathrm{H}$ chemical bonds were a result of the biological functional groups. The presence of these bands proved that partial biological functional groups could be retained at a calcination temperature of $400^{\circ} \mathrm{C}$, while the biological functional groups were completely decomposed at $800{ }^{\circ} \mathrm{C}$. The precursor BMB was composed of biogenic Mn oxides and organic carbon (Figures 2 and S1). The excessive cation vacancies in biogenic Mn oxides and the presence of biological functional groups in organic carbon could lead to very low internal electronic conductivity. However, the metastable cation vacancies and biological functional groups could be removed by proper high temperature treatment. Thus, the organic carbon was converted to inorganic carbon with improved conductivity [34,35]. Raman spectra show two characteristic peaks in $\mathrm{B} 800$ at 1344.47 and $1580.75 \mathrm{~cm}^{-1}$, which correspond to the D- (disorder carbon) and G-bands (graphitic carbon), respectively. The peaks at $630.7 \mathrm{~cm}^{-1}$ are in accordance with the characteristic vibration mode of $\mathrm{Mn}_{3} \mathrm{O}_{4}$ rather than $\mathrm{MnO}_{2}$ or $\mathrm{MnO}$, which mainly attributed to the local heating effect and photochemically induced transformations under beam irradiation (Figure S8) [1]. This result demonstrates the presence of Mn-O and consistent with the FT-IR data. According to the SEM, FT-IR and Raman spectra analysis results, the materials obtained at a carbonization temperature of $800{ }^{\circ} \mathrm{C}$ (B800 and CMB-Ni) exhibited better morphology and complete decomposition of biological functional groups, therefore, it was selected for subsequent studies.

The phase composition of the B800 and CMB-Ni, as well as the phase evolution after high-temperature annealing, was compared and analyzed by XRD (Figure $4 a, b)$. The results showed that B800 contained four phases, i.e., $\mathrm{MnO}$ (JCPDS card no. 78-0424), $\mathrm{MnCO}_{3}$ (JCPDS card no. 85-1109), $\mathrm{CaCO}_{3}$ (JCPDS card no. 17-0763) and $\mathrm{MnSO}_{4}$ (JCPDS card no. 29-0898) (Figure 4a). The diffraction peaks in the spectra were attributed to the (111), (200), (220), (311) and (222) planes of $\mathrm{MnO}$, the (012), (104) and (110) planes of $\mathrm{MnCO}_{3}$, the (110), (021), (111) and (042) planes of $\mathrm{MnSO}_{4}$, and the (220) and (221) planes of $\mathrm{CaCO}_{3}$. The diffraction peaks of some phases were overlapped, for example, (221) of $\mathrm{CaCO}_{3}$ and (104) of $\mathrm{MnCO}_{3}$, and (111) of $\mathrm{MnSO}_{4}$ and (012) of $\mathrm{MnCO}_{3}$. CMB-Ni (Figure 4b) also contained the four phases described above. However, in addition, new phases of NiO (JCPDS card no. 44-1159) and MnS (JCPDS card no. 06-0518) were observed in CMB-Ni. The new diffraction peaks corresponded to the (101), (110) and (202) planes of $\mathrm{NiO}$, and the (200), (220) and (420) planes of MnS. The discrepancy of the phase compositions in B800 and CMB-Ni might be explained as follows. The reducing atmosphere was generated in the annealing process due to the decomposition of biological carbon. Then, $\mathrm{Na}_{0.7} \mathrm{MnO}_{2}$ in $\mathrm{BMB}$ was reduced to $\mathrm{MnO} . \mathrm{Na}_{2} \mathrm{~S}_{2} \mathrm{O}_{4}$ reacted with residual $\mathrm{Mn}^{2+}$ to form $\mathrm{MnSO}_{4} \cdot \mathrm{MnS}_{\text {was }}$ the common product in Mn oxidation when the oxygen supply was insufficient [29]. The components, including $\mathrm{CaCO}_{3}$ and $\mathrm{MnCO}_{3}$, remained. The XRD analysis of $\mathrm{B} 400$ and $\mathrm{B} 600$ also proved this conclusion (Figure S9). B400 was incompletely reduced to form $\mathrm{Mn}_{2} \mathrm{O}_{3}$ (JCPDS card no. 71-0635) under reducing atmosphere. Moreover, the background of the diffraction pattern was relatively high and the characteristic diffraction peaks were not obvious, indicating that the organic matter in the material was partially decomposed. The high background signal interference still existed. At higher temperatures, B600 and B800 were fully reduced to $\mathrm{MnO}$. As a result, the characteristic diffraction peaks were clear and sharp. The good crystallization confirmation indicates the significant decrease of organic matter content, consistent with the FT-IR and TGA results for B800. 


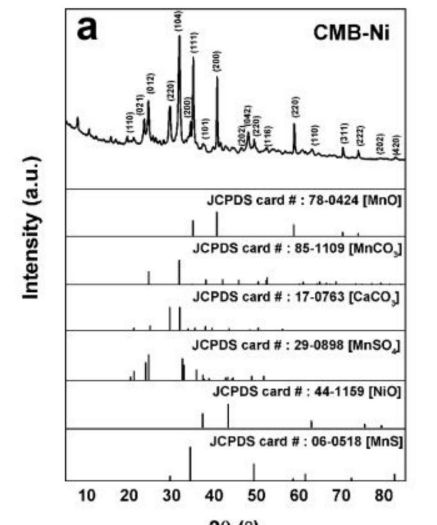
$2 \theta\left(^{\circ}\right)$
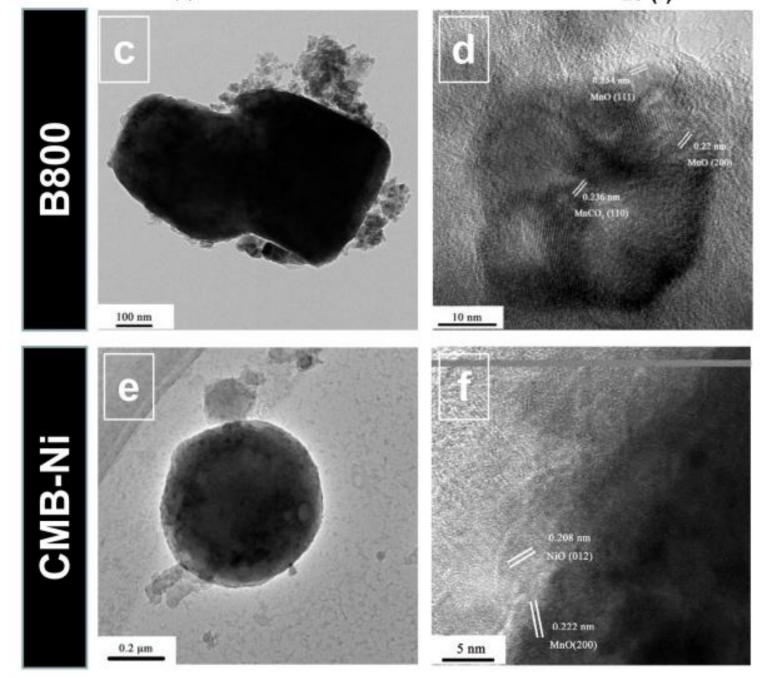

Figure 4. XRD patterns and corresponding HRTEM of materials prepared at $800^{\circ} \mathrm{C}$. In (a,b): XRD patterns of CMB-Ni and B800. The Bragg positions and intensities are marked. In HRTEM micrographs, (c,e): the skeleton structure of B800 and CMB-Ni; $(\mathbf{d}, \mathbf{f})$ : the measured crystal lattice spacings of B800 and CMB-Ni.

The microstructures of B800 and CMB-Ni were further analyzed by HRTEM. Under calcination conditions of $800^{\circ} \mathrm{C}$, the incorporating of metal ions did not change the overall structure of the material, which was still irregularly spherical (Figure 4c,e). In B800, the interplanar spacing of the main lattice image was $0.22 \mathrm{~nm}$, which could be attributed to the (200) planes of $\mathrm{MnO}$. However, a situation where three lattice fringes were stacked with each other was also observed. The lattice fringe with interplanar spacings of 0.254 and $0.22 \mathrm{~nm}$ was attributed to the (111) and (200) planes of $\mathrm{MnO}$, respectively. The lattice fringe with an interplanar spacing of $0.236 \mathrm{~nm}$ was attributed to the (110) plane of $\mathrm{MnCO}_{3}$ (Figure 4d). The main existing lattice images in CMB-Ni was similar to those in B800, i.e., corresponding to $\mathrm{MnO}$ and $\mathrm{MnCO}_{3}$. However, the interplanar spacing of the lattice fringe corresponding to $\mathrm{MnCO}_{3}$ in $\mathrm{CMB}-\mathrm{Ni}$ was $0.175 \mathrm{~nm}$, which could be attributed to the (018) planes. Apart from the major phases, including $\mathrm{MnO}$ and $\mathrm{MnCO}_{3}$, the special lattice fringes of $\mathrm{NiO}$ was also observed in CMB-Ni. The interplanar spacing of $0.208 \mathrm{~nm}$ in CMB-Ni was attributed to the (012) planes of $\mathrm{NiO}$ (Figure 4f). These results were consistent with the XRD analysis, i.e., multi-phases existed in the materials and $\mathrm{MnO}$ and $\mathrm{MnCO}_{3}$ were major phases. The valence state of new Mn oxides formed in the thermochemical reduction process was analyzed by XPS. The spectral fitting results of the $\operatorname{Mn}\left(2 \mathrm{p}_{3 / 2}\right)$ spectrogram for $\mathrm{B} 800$ indicated that there were three valence states, i.e., $\mathrm{Mn}^{2+}, \mathrm{Mn}^{3+}$ and $\mathrm{Mn}^{4+}$ (Figure S10a), with a proportion of the corresponding peak intensity by $81.44 \%$, $9.66 \%$ and $8.9 \%$, respectively (Table S2). This proved that the main oxidation state of $\mathrm{Mn}$ was converted from $\mathrm{Mn}^{4+}$ to $\mathrm{Mn}^{2+}$ after high temperature reduction. Meanwhile, a 
few high-valence Mn ions still existed, and this was consistent with the results of XRD. However, the diffraction peaks of $\mathrm{Mn}^{3+}$ and $\mathrm{Mn}^{4+}$ were not found in the XRD spectrum, which was possibly caused by the covering of the signal by background due to their very low contents. A similar valence proportion was also observed in CMB-Ni (Figure S10b, Table S2). The phases in the materials after annealing treatment mainly included $\mathrm{MnO}$ and $\mathrm{MnCO}_{3}$. Meanwhile, multi-phases were embedded in the porous carbonaceous network. The foreign oxides could act as dispersants for others in the annealing process, and inhibit the aggregation in the lithiation process and the generation of heterogeneous oxides in electrochemical cycling [10].

\subsection{Electrochemical Determination of the Composites as Anodes for Lithium-Ion Batteries}

The redox reaction of electrode materials was measured by cyclic voltammetry curves. The reduction peak near $0.1 \mathrm{~V}$ in the first cathode scanning for B800 presented the reduction from $\mathrm{Mn}^{2+}$ to $\mathrm{Mn}^{0}$ and the formation of a solid electrolyte interface (SEI) layer [36]. The oxidation peak at $1.25 \mathrm{~V}$ in the anode scanning was due to the oxidization reaction from the $\mathrm{Mn}^{0}$ to $\mathrm{Mn}^{2+}$ (Figure 5a) [1]. The redox peak intensity of cyclic voltammetry curve increased with increasing scan times, indicating the enhancement of electrochemical activity with the increase of Li ions in subsequent cycles [37].
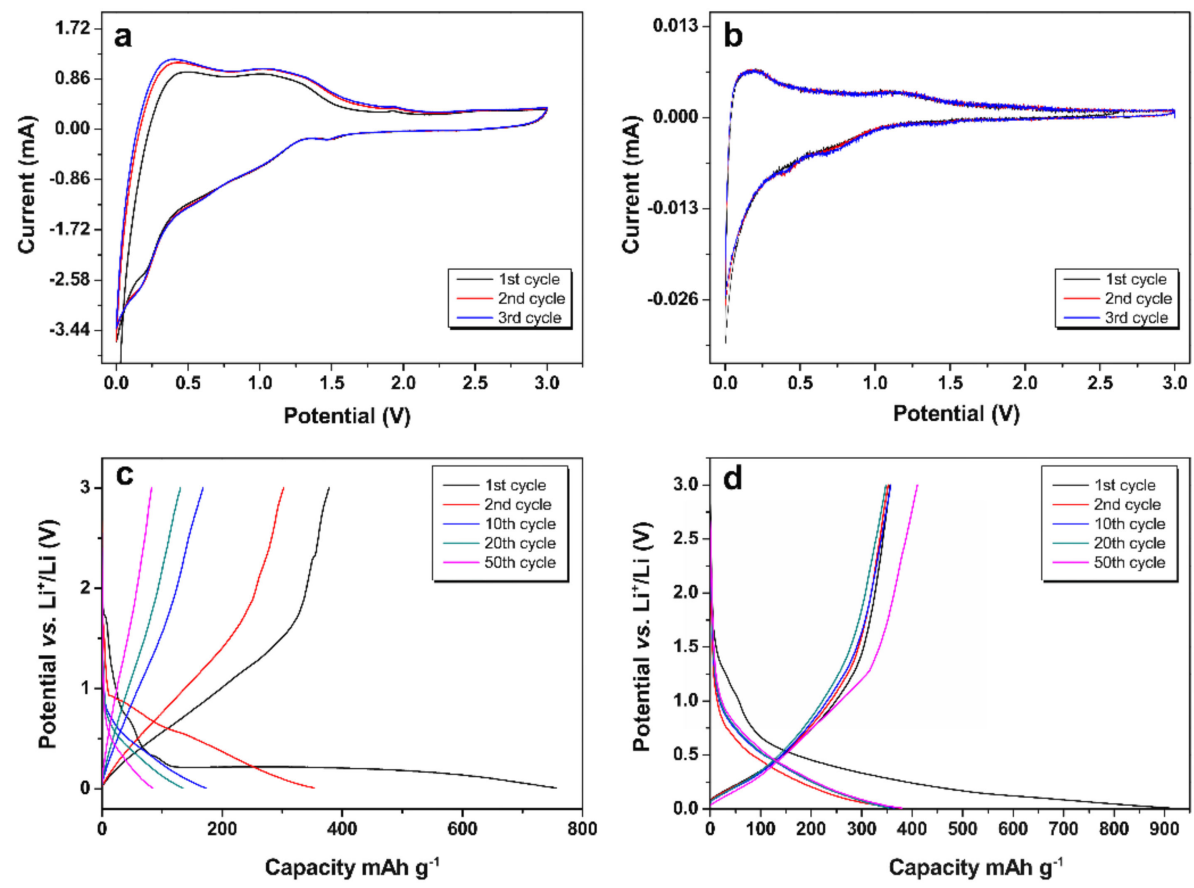

Figure 5. Cyclic voltammetry curves of (a) B800 and (b) CMB-Ni at a scan rate of $0.1 \mathrm{mV} \mathrm{s}^{-1}$. Charge-discharge profiles of (c) B800 and (d) CMB-Ni at different cycles with a current density of $0.1 \mathrm{~A} \mathrm{~g}^{-1}$.

Compared with B800, the first reduction peak of CMB-Ni shifted to $0.4 \mathrm{~V}$. This indicated the occurrence of an irreversible phase change conversion, which was caused by the formation of $\mathrm{Li}_{2} \mathrm{O}$ and metallic $\mathrm{Mn}$ [1]. The new reduction peak at $0.8 \mathrm{~V}$ was possibly related to the presence of $\mathrm{NiO}$, which corresponded to the reduction from $\mathrm{Ni}^{2+}$ to $\mathrm{Ni}^{0}$ in electrochemical cycling $[34,38]$. The oxidation peak at $1.25 \mathrm{~V}$ in the anode scan was due to the oxidation from $\mathrm{Mn}^{0}$ to $\mathrm{Mn}^{2+}$ and from $\mathrm{Ni}^{0}$ to $\mathrm{Ni}^{2+}$ (Figure 5b) [1,38]. The cyclic voltammetry curves of $\mathrm{CMC}-\mathrm{Ni}$ in several cycles almost coincided, indicating the good electrochemical reversibility of the material.

The constant current charge-discharge profiles $(0-3 \mathrm{~V})$ of B800 with a current density of $0.1 \mathrm{~A} \mathrm{~g}^{-1}$ are shown in Figure 5c. As can be seen, the initial discharge and charge capacities were 756.1 and $377.7 \mathrm{mAh} \mathrm{g}^{-1}$, respectively. The Coulombic efficiency in the 
first cycle was $49.9 \%$. However, the reversible discharge capacity dramatically decreased to $84.21 \mathrm{mAh} \mathrm{g}^{-1}$ after 50 cycles. The capacity degradation in the cycling process may due to the irreversible phase transition caused by the Jahn-Teller effect and the disproportionation reaction caused by $\mathrm{Mn}$ dissolution into the electrolyte [4]. A long and smooth discharge plateau was observed near $0.1 \mathrm{~V}$ in the first discharge process, which may attributable to the formation of a SEI layer and the reduction from $\mathrm{Mn}^{2+}$ to $\mathrm{Mn}^{0}$. However, the discharge plateau shifted to about $0.8 \mathrm{~V}$ for the second cycle due to the polarization phenomenon. The charge plateau was observed at around $1.5 \mathrm{~V}$ in the charge process. The large particles in the active material would be reduced to nano-metal particles in the first discharge. A high driving force and additional energy were required to supplement the interface energy and surface energy in this process, leading to the polarization phenomenon. The active materials had been fully activated in the following cycles. The requirements of energy compensation and reaction driving force greatly decreased. As a result, the discharge plateau rose, while the polarization phenomenon was obviously reduced $[39,40]$. The initial discharge capacities for CMB-Ni was $909.84 \mathrm{mAh} \mathrm{g}^{-1}$ at $0.1 \mathrm{~A} \mathrm{~g}^{-1}$ current density. The Coulombic efficiencies in the first cycle was $39.2 \%$ (Figure $5 \mathrm{~d}$ ). The additional discharge capacity of CMB-Ni compared to the theoretical capacity was possibly from the decomposition of the electrolyte in the formation of the SEI layer and the contribution of graphite $[1,41,42]$. Both materials, before and after incorporating, showed an irreversible loss of first discharge capacity, which was due to the decomposition of the electrolyte and the formation of the SEI layer $[1,41,43]$. For CMB-Ni, the polarization phenomenon was reduced. The discharge and charge plateaus were at 0.7 and $1.3 \mathrm{~V}$, respectively. Note that the voltage hysteresis effect was eliminated for CMB-Ni in the long-term cycle process. The charge plateau at 1.3-1.5 V also indicated a high open circuit voltage and energy density when the materials were assembled with a specific cathode. The electrochemical testing results above proved that CMB-Ni exhibited better electrochemical properties; in particular, the capacity loss was zero after the second cycle.

The cycling and rate performances of composites obtained under different treatment conditions as anodes for lithium-ion batteries were comparatively analyzed to investigate the influence of calcination temperature and incorporated method on the electrochemical properties. In the calculation of specific capacity, the mass of the active materials reflects the total mass of amorphous carbon and metal oxides. B800 exhibited better cycling performance and rate properties than B600 and B400 (Figure 6a). In comparison with B600 and B400, B800 exhibited a much higher reversible specific capacity. This might be a consequence of the formation of $\mathrm{MnO}$ and $\mathrm{C}$, which are the phases that lithiated well. However, rapidly capacity fade was still observed for B800. In rate performance tests of CMB-Ni, the reversible discharge specific capacity of CMB-Ni was 468.95, 390.48, 367.78, $265.44,210.52$, and $450.08 \mathrm{mAh} \mathrm{g}^{-1}$ when the current density was $0.1,0.2,0.5,1,3$, and $0.1 \mathrm{Ag}^{-1}$, respectively (Figure 6a), indicating that CMB-Ni had the best rate performance.

Figure $6 \mathrm{~b}$ presents the specific capacity change of different materials within 200 cycles at a current density of $0.1 \mathrm{~A} \mathrm{~g}^{-1}$. The cycling capacity of the non-carbonized BMB material was the lowest. The initial discharge capacity was $335.9 \mathrm{mAh} \mathrm{g}^{-1}$ and the reversible discharge capacity after 200 cycles was only $19.39 \mathrm{mAh} \mathrm{g}^{-1}$. After calcination treatment, the cycling capacities of B400, B600 and B800 gradually increased with increasing calcination temperature. The initial discharge capacities were $569.52,756.14$ and $747.7 \mathrm{mAh} \mathrm{g}^{-1}$, respectively. After 200 cycles, the reversible discharge capacities changed to 56.14, 35.78 and $117.22 \mathrm{mAh} \mathrm{g}^{-1}$, respectively. Wherein, the initial discharge capacities of B600 and B800 were comparable to the theoretical capacity of $\mathrm{MnO}\left(756 \mathrm{mAh} \mathrm{g}^{-1}\right)$. Apparently, the discrepancy in reversible cycling capacity was related to the removal effect of biological functional groups and cation vacancies in the materials. In addition, bound water components in the organic matter also caused the increase of contact resistance and the decomposition of electrolyte lithium salt, which further deteriorated the cycling performance of the battery [44]. The treatment at high temperature could also eliminate the influence of bound water components $[34,35,44]$. Similarly, after incorporated with metal ions, the 
cycling stability of CMB-Ni was greatly improved. The reversible discharge capacities of CMB-Ni at $0.1 \mathrm{~A} \mathrm{~g}^{-1}$ after 50 cycles was $379.29 \mathrm{mAh} \mathrm{g}^{-1}$, after 200 cycles, it can still be stable at a capacity of $356.76 \mathrm{mAh} \mathrm{g}^{-1}$. The discharge specific capacity of CMB-Ni was basically unchanged after the second cycle, and the Coulombic efficiency always stabilized at around $100 \%$. The cycling performance for CMB-Ni improved because the multiphase metal oxides inhibited the aggregation in the lithiation process and the generation of heterogeneous oxides $[9,10,45]$. These results also show that the reversible charge capacities for all samples are far from theoretical capacities of $\mathrm{MnO}$ and $\mathrm{NiO}$. The large capacity loss is mainly attributed to the irreversible processes such as electrolyte decomposition and inevitable formation of the SEI layer in the first cycle [1].

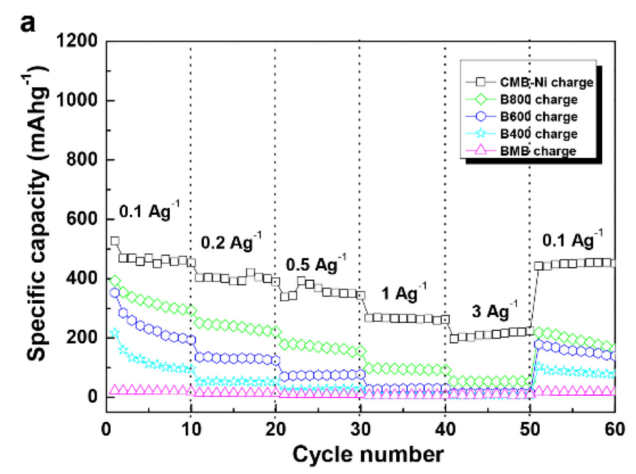

b

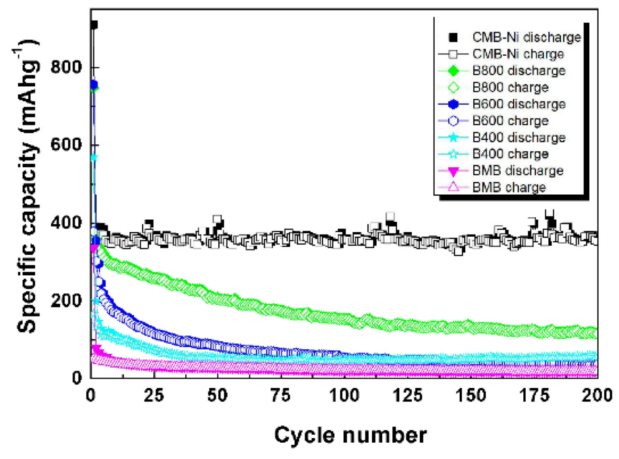

Figure 6. Comparison of (a) rate performance of CMB-Ni, B800, B600, B400, and BMB electrodes at different current densities and (b) their cycling performance at $0.1 \mathrm{~A} \mathrm{~g}^{-1}$ current density. All were tested from $0 \mathrm{~V}$ to $3.0 \mathrm{~V}$ (vs. $\mathrm{Li} / \mathrm{Li}^{+}$).

Ping et al. have previously verified the feasibility of fabricating a carbon-coating anatase anode using the cell surface display and biological template method, with a maximum specific capacity of $207 \mathrm{mAh} \mathrm{g}^{-1}$ (200 cycles) at 1C current intensity [46]. Unfortunately, the electrochemical capacity of this material seems to be difficult to improve by metal incorporation due to the intrinsic feature of the anatase and the limitation of the conventional biotemplate method for metal oxide synthesis. Moreover, several previously developed MnO-based electrode materials using biological template methods exhibited higher levels of electrochemical capacity, with maximum specific capacities at $700 \mathrm{mAh} \mathrm{g}^{-1}$ (0.1 $\mathrm{Ag}^{-1}, 50$ cycles) for $\mathrm{MnO} / \mathrm{C}$ microspheres [1], $610 \mathrm{mAh} \mathrm{g}^{-1}\left(0.2 \mathrm{Ag}^{-1}, 60\right.$ cycles $)$ for $\mathrm{MnO} / \mathrm{C}$ microtubes [37], and $730 \mathrm{mAh} \mathrm{g}^{-1}\left(0.1 \mathrm{Ag}^{-1}, 50\right.$ cycles) [47] (Table S4). However, these electrode materials also subjected to the capacity fade and polarization phenomenon in the cycling performance. Although the absolute specific capacity of the current composite (CMB-Ni) is not very high due to relatively low contents of $\mathrm{Mn}$ in materials, the significant cycle stability with nearly zero loss and polarization for $\mathrm{CMB}-\mathrm{Ni}$, prove the ability of this novel biomineralization method. It is expected that the proposed method could be extended to other biological templates to prepare new materials with improved electrochemical properties. 


\section{Conclusions}

In conclusion, a facile incoporating method for Mn-based electrode materials was designed using combined bacterial surface display and biotemplate method. The mineralization ability of the engineered P. putida MB285 cells with surface-oriented $\mathrm{Mn}^{2+}$-oxidizing activity was utilized. The aggregates formed in the mineralization process were used as the biological template. Based on the settler character of biogenic Mn oxides for metal ions, the incoporating of $\mathrm{Ni}$ cations was realized under mild conditions. The $\mathrm{MnO} / \mathrm{C} / \mathrm{NiO}$ porous multiphasic composites were fabricated by annealing and exhibited good cycling performance in electrochemical testing, the reversible discharge capacity of CMB-Ni remained at $352.92 \mathrm{mAh} \mathrm{g}^{-1}$ after 200 cycles at $0.1 \mathrm{~A} \mathrm{~g}^{-1}$ current density and the coulombic efficiency was approximately $100 \%$ after the second cycle for CMB-Ni, indicating its significant potential for use in lithium-ion batteries. However, there are also problems in this method, such as the long time it took to produce the biogenic Mn oxides, but these could be improved by constructing an engineered strain with a higher $\mathrm{Mn}^{2+}$-oxidizing activity in further experiments. The facile biomineralization-based preparation process and novel incorporation method in this study also holds great translational promise in other similar fields.

Supplementary Materials: The following are available online at https://www.mdpi.com/2079-4 991/11/2/361/s1, Figure S1: TGA-DSC curves of BMB. Figure S2: FT-IR spectra of the BMB, pure bacteria cells and pure bacteria cells with $\mathrm{MnCl} 2$ without cultivation. Figure S3: SEM images of the products prepared at $(\mathrm{a}, \mathrm{b}) 400^{\circ} \mathrm{C}(\mathrm{B} 400)$ and $(\mathrm{c}, \mathrm{d}) 600^{\circ} \mathrm{C}(\mathrm{B} 600)$. Figure S4: Pore size distribution curve of the samples under calcination conditions of (a) $400{ }^{\circ} \mathrm{C}$ (B400), (b) $600{ }^{\circ} \mathrm{C}$ (B600) and $800{ }^{\circ} \mathrm{C}$ (c:B800; d: CMB-Ni). Figure S5: Line-scan SEM-EDS analysis of B800. Figure S6: TGA-DSC curves of (a) B400, (b) B600, (c) B800 and (d) CMB-Ni. Figure S7: Line-scan SEM-EDS analysis of CMB-Ni. Figure S8: Raman spectra of B800 annealed under Ar atmospheres. Figure S9: XRD patterns of (A) B600 and (B) B400. The Bragg positions and intensities are marked. Figure S10: XPS patterns of the $\mathrm{Mn}\left(2 \mathrm{p}_{3 / 2}\right)$ spectrogram of B800 and CMB-Ni prepared at $800^{\circ} \mathrm{C}$. The upper circles represent the observed data. The thick, solid curve indicates the best fit of the data. The dashed-dotted curves represent the $\mathrm{Mn}^{4+}$ multiplet peaks, the dotted lines represent $\mathrm{Mn}^{3+}$, and the thin solid lines represent $\mathrm{Mn}^{2+}$. Table S1: Compositions of surface elements in biogenic $\mathrm{MnO}_{2} /$ bacteria composites analyzed by line-scan EDS. Table S2: Near-surface composition of Mn species derived from fittings of Mn $\left(2 p_{3 / 2}\right)$ spectra. Table S3: Composition of surface elements in B800 analyzed by line-scan EDS.

Author Contributions: J.L. performed most of the experiments, made most of the data evaluation and interpretation, and drafted the manuscript; T.G. and L.L. (Li Li) participated in partial experiments, and L.L. (Lin Li) conceived and directed the study and revised the manuscript. All authors have read and agreed to the published version of the manuscript.

Funding: This work was supported by grants from the National Natural Science Foundation of China (grant Nos. 31770108 and 31570123).

Data Availability Statement: Data available in a publicly accessible repository.

Acknowledgments: The authors are grateful to Xinping Ai at Wuhan University for his technical assistance with the lithium-ion battery assembly experiments, Jian Ye and Bolun Jiang at Wuhan University, and Hong $\mathrm{Ni}$ and Rulin Lei at Hubei University for their assistance in the electrochemistry experiments and data analysis.

Conflicts of Interest: The authors declare no conflict of interest.

\section{References}

1. Xia, Y.; Xiao, Z.; Dou, X.; Huang, H.; Lu, X.; Yan, R.; Gan, Y.; Zhu, W.; Gu, C.; Zhang, W.; et al. Green and Facile Fabrication of Hollow Porous MnO/C Microspheres from Microalgaes for Lithium-Ion Batteries. ACS Nano 2013, 7, 7083-7092. [CrossRef]

2. Wu, M.S.; Chang, H.W. Self-Assembly of NiO-Coated ZnO Nanorod Electrodes with Core-Shell Nanostructures as Anode Materials for Rechargeable Lithium-Ion Batteries. J. Phys. Chem. 2013, 117, 2590-2599. [CrossRef]

3. Tao, X.; Wu, R.; Xia, Y.; Huang, H.; Chai, W.; Feng, T.; Gan, Y.; Zhang, W. Biotemplated Fabrication of Sn@C Anode Materials Based on the Unique Metal Biosorption Behavior of Microalgae. ACS Appl. Mater. Interfaces 2014, 6, 3696-3702. [CrossRef] 
4. Zhang, K.; Han, X.; Hu, Z.; Zhang, X.; Tao, Z.; Chen, J. Nanostructured Mn-based oxides for electrochemical energy storage and conversion. Chem. Soc. Rev. 2015, 44, 699-728. [CrossRef]

5. Zeng, J.; Wang, S.; Yu, J.; Cheng, H.; Tan, H.; Liu, Q.; Wu, J. Al and/or Ni-doped nanomanganese dioxide with anisotropic expansion and their electrochemical characterisation in primary Li-MnO2 batteries. J. Solid State Electrochem. 2014, 18, 1585-1591. [CrossRef]

6. Cabana, J.; Monconduit, L.; Larcher, D.; Palacin, M.R. Beyond Intercalation-Based Li-Ion Batteries: The State of the Art and Challenges of Electrode Materials Reacting Through Conversion Reactions. Adv. Mater. 2010, 22, E170-E192. [CrossRef]

7. Opra, D.; Gnedenkov, S.; Sokolov, A.; Podgorbunsky, A.; Ustinov, A.; Mayorov, V.; Kuryavyi, V.; Sinebryukhov, S. Vanadiumdoped TiO2-B/anatase mesoporous nanotubes with improved rate and cycle performance for rechargeable lithium and sodium batteries. J. Mater. Sci. Technol. 2020, 54, 181-189. [CrossRef]

8. Opra, D.; Gnedenkov, S.; Sinebryukhov, S.; Podgorbunsky, A.; Sokolov, A.; Ustinov, A.; Kuryavyi, V.; Mayorov, V.; Zheleznov, V. Doping of titania with manganese for improving cycling and rate performances in lithium-ion batteries. Chem. Phys. 2020, 538, 110864. [CrossRef]

9. Liu, W.; Yao, T.-H.; Xie, S.; She, Y.; Wang, H. Integrating TiO2/SiO2 into Electrospun Carbon Nanofibers towards Superior Lithium Storage Performance. Nanomaterials 2019, 9, 68. [CrossRef]

10. Li, T.; Wang, Y.-Y.; Tang, R.; Qi, Y.-X.; Lun, N.; Bai, Y.-J.; Fan, R.-H. Carbon-Coated Fe-Mn-O Composites as Promising Anode Materials for Lithium-Ion Batteries. ACS Appl. Mater. Interfaces 2013, 5, 9470-9477. [CrossRef]

11. Han, L.; Shao, C.; Liang, B.; Liu, A. Genetically engineered phage-templated MnO2 nanowires: Synthesis and their application in electrochemical glucose biosensor operated atneutral pH condition. ACS Appl. Mater. Interfaces 2016, 8, 13768-13776. [CrossRef]

12. Cao, B.; Yang, M.; Mao, C. Phage as a Genetically Modifiable Supramacromolecule in Chemistry, Materials and Medicine. ACC Chem. Res. 2016, 49, 1111-1120. [CrossRef]

13. Zhang, Z.; Zhang, Z.; Chen, H.; Liu, J.; Liu, C.; Ni, H.; Zhao, C.; Ali, M.; Liu, F.; Li, L. Surface Mn(II) oxidation actuated by a multicopper oxidase in a soil bacterium leads to the formation of manganese oxide minerals. Sci. Rep. 2015, 5, 10895. [CrossRef]

14. Takahashi, Y.; Manceau, A.; Geoffroy, N.; Marcus, M.A.; Usui, A. Chemical and structural control of the partitioning of Co, Ce, and $\mathrm{Pb}$ in marine ferromanganese oxides. Geochim. Cosmochim. Acta 2007, 71, 984-1008. [CrossRef]

15. Lee, Y.; Tebo, B.M. Cobalt(II) Oxidation by the Marine Manganese(II)-Oxidizing Bacillus sp. Strain SG-1. Appl. Environ. Microbiol. 1994, 60, 2949-2957. [CrossRef]

16. Manceau, A.; Lanson, M.; Geoffroy, N. Natural speciation of Ni, Zn, Ba, and As in ferromanganese coatings on quartz using X-ray fluorescence, absorption, and diffraction. Geochim. Cosmochim. Acta 2007, 71, 95-128. [CrossRef]

17. Romano, C.A.; Zhou, M.; Song, Y.; Wysocki, V.H.; Dohnalkova, A.C.; Kovarik, L.; Paša-Tolić, L.; Tebo, B.M. Biogenic manganese oxide nanoparticle formation by a multimeric multicopper oxidase Mnx. Nat. Commun. 2017, 8, 1-8. [CrossRef]

18. Wang, W.; Zhang, Z.; Ni, H.; Yang, X.; Li, Q.; Li, L. Decolorization of industrial synthetic dyes using engineered Pseudomonas putida cells with surface-immobilized bacterial laccase. Microb. Cell Factories 2012, 11, 75. [CrossRef]

19. Su, J.; Deng, L.; Huang, L.; Guo, S.; Liu, F.; He, J. Catalytic oxidation of manganese(II) by multicopper oxidase CueO and characterization of the biogenic Mn oxide. Water Res. 2014, 56, 304-313. [CrossRef]

20. Caspi, R.; Tebo, B.M.; Haygood, M.G. c-type cytochromes and manganese oxidation in Pseudomonas putida MnB1. Appl. Environ. Microbiol. 1998, 64, 3549-3555. [CrossRef]

21. Johnson, H.A.; Tebo, B.M. In vitro studies indicate a quinone is involved in bacterial Mn(II) oxidation. Arch. Microbiol. 2007, 189, 59-69. [CrossRef] [PubMed]

22. Singh, S.K.; Grass, G.; Rensing, C.; Montfort, W.R. Cuprous Oxidase Activity of CueO from Escherichia coli. J. Bacteriol. 2004, 186, 7815-7817. [CrossRef] [PubMed]

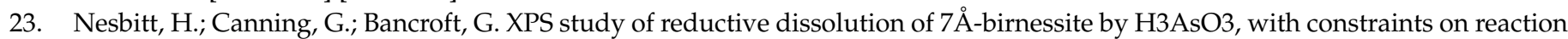
mechanism. Geochim. Cosmochim. Acta 1998, 62, 2097-2110. [CrossRef]

24. Yin, H.; Liu, F.; Feng, X.; Liu, M.; Tan, W.; Qiu, G. Co2+-exchange mechanism of birnessite and its application for the removal of $\mathrm{Pb} 2+$ and $\mathrm{As}(\mathrm{III})$. J. Hazard. Mater. 2011, 196, 318-326. [CrossRef] [PubMed]

25. Tebo, B.M.; Bargar, J.R.; Clement, B.G.; Dick, G.J.; Murray, K.J.; Parker, D.; Verity, R.; Webb, S.M. BIOGENIC MANGANESE OXIDES: Properties and Mechanisms of Formation. Annu. Rev. Earth Planet. Sci. 2004, 32, 287-328. [CrossRef]

26. Tebo, B.M.; Johnson, H.A.; McCarthy, J.K.; Templeton, A.S. Geomicrobiology of manganese (II) oxidation. Trends Microbiol. 2005, 13, 421-428. [CrossRef]

27. Butterfield, C.N.; Soldatova, A.V.; Lee, S.-W.; Spiro, T.G.; Tebo, B.M. Mn (II,III) oxidation and MnO2 mineralization by an expressed bacterial multicopper oxidase. Proc. Natl. Acad. Sci. USA 2013, 110, 11731-11735. [CrossRef]

28. Kruk, M.; Jaroniec, M. Gas Adsorption Characterization of Ordered Organic-Inorganic Nanocomposite Materials. Chem. Mater. 2001, 13, 3169-3183. [CrossRef]

29. Benner, S.G.; Blowes, D.W.; Gould, W.D.; Herbert, R.B.; Ptacek, C.J. Geochemistry of a Permeable Reactive Barrier for Metals and Acid Mine Drainage. Environ. Sci. Technol. 1999, 33, 2793-2799. [CrossRef]

30. Yang, W.; Zhang, Z.; Zhang, Z.; Chen, H.; Liu, J.; Ali, M.; Liu, F.; Li, L. Population Structure of Manganese-Oxidizing Bacteria in Stratified Soils and Properties of Manganese Oxide Aggregates under Manganese-Complex Medium Enrichment. PLoS ONE 2013, 8, e73778. [CrossRef] 
31. Mandernack, K.W.; Post, J.; Tebo, B.M. Manganese mineral formation by bacterial spores of the marine Bacillus, strain SG-1: Evidence for the direct oxidation of Mn(II) to Mn(IV). Geochim. Cosmochim. Acta 1995, 59, 4393-4408. [CrossRef]

32. Webb, S.M.; Dick, G.J.; Bargar, J.R.; Tebo, B.M. Evidence for the presence of Mn(III) intermediates in the bacterial oxidation of Mn(II). Proc. Natl. Acad. Sci. USA 2005, 102, 5558-5563. [CrossRef] [PubMed]

33. Omid, H.; Oghabian, M.A.; Ahmadi, R.; Shahbazi, N.; Hosseini, H.R.M.; Shanehsazzadeh, S.; Zangeneh, R.N. Synthesizing and staining manganese oxide nanoparticles for cytotoxicity and cellular uptake investigation. Biochim. Biophys. Acta (BBA) Gen. Subj. 2014, 1840, 428-433. [CrossRef] [PubMed]

34. Shim, H.-W.; Jin, Y.-H.; Seo, S.-D.; Lee, S.-H.; Kim, D.-W. Highly Reversible Lithium Storage in Bacillus subtilis-Directed Porous Co3O4 Nanostructures. ACS Nano 2010, 5, 443-449. [CrossRef]

35. Hahn, B.P.; Long, J.W.; Rolison, D.R. Something from Nothing: Enhancing Electrochemical Charge Storage with Cation Vacancies. Acc. Chem. Res. 2013, 46, 1181-1191. [CrossRef]

36. Sun, B.; Chen, Z.; Kim, H.-S.; Ahn, H.; Wang, G. MnO/C core-shell nanorods as high capacity anode materials for lithium-ion batteries. J. Power Sources 2011, 196, 3346-3349. [CrossRef]

37. Wang, J.; Liu, W.; Chen, J.; Wang, H.; Liu, S.; Chen, S. Biotemplated MnO/C microtubes from spirogyra with improved electrochemical performance for lithium-ion batterys. Electrochim. Acta 2016, 188, 210-217. [CrossRef]

38. Huang, X.; Tu, J.; Zhang, B.; Zhang, C.; Li, Y.; Yuan, Y.; Wu, H. Electrochemical properties of NiO-Ni nanocomposite as anode material for lithium ion batteries. J. Power Sources 2006, 161, 541-544. [CrossRef]

39. Taberna, P.-L.; Mitra, S.; Poizot, P.; Simon, P.; Tarascon, J.-M. High rate capabilities Fe3O4-based Cu nano-architectured electrodes for lithium-ion battery applications. Nat. Mater. 2006, 5, 567-573. [CrossRef]

40. Hong, L.; Balaya, P.; Maier, J. Li-storage via heterogeneous reaction in aelected binary metal fluorides and oxides. J. Electrochem. Soc. 2004, 151, A1878-A1885.

41. Xu, G.-L.; Xu, Y.-F.; Sun, H.; Fu, F.; Zheng, X.-M.; Huang, L.; Li, J.-T.; Yang, S.; Sun, S.-G. Facile synthesis of porous MnO/C nanotubes as a high capacity anode material for lithium ion batteries. Chem. Commun. 2012, 48, 8502-8504. [CrossRef] [PubMed]

42. Zhang, K.; Han, P.; Gu, L.; Zhang, L.; Liu, Z.; Kong, Q.; Zhang, C.; Dong, S.; Zhang, Z.; Yao, J.; et al. Synthesis of Nitrogen-Doped

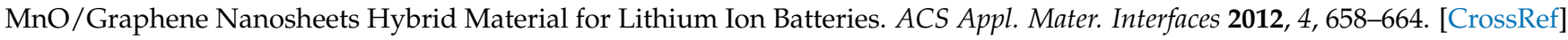
[PubMed]

43. Ding, Y.; Wu, C.; Yu, H.; Xie, J.; Cao, G.; Zhu, T.; Zhao, X.B.; Zeng, Y. Coaxial MnO/C nanotubes as anodes for lithium-ion batteries. Electrochim. Acta 2011, 56, 5844-5848. [CrossRef]

44. Aurbach, D.; Weissman, I.; Zaban, A.; Dan, P. On the role of water contamination in rechargeable Li batteries. Electrochim. Acta 1999, 45, 1135-1140. [CrossRef]

45. Zhou, Y.; Zhu, Q.; Tian, J.; Jiang, F. TiO2 Nanobelt@Co9S8 Composites as Promising Anode Materials for Lithium and Sodium Ion Batteries. Nanomaterials 2017, 7, 252. [CrossRef]

46. Ping, H.; Xie, H.; Xiang, M.; Su, B.-L.; Wang, Y.; Zhang, J.; Zhang, F.; Fu, Z. Confined-space synthesis of nanostructured anatase, directed by genetically engineered living organisms for lithium-ion batteries. Chem. Sci. 2016, 7, 6330-6336. [CrossRef]

47. Zhu, W.; Huang, H.; Zhang, W.; Tao, X.; Gan, Y.; Xia, Y.; Yang, H.; Guo, X. Synthesis of MnO/C composites derived from pollen template for advanced lithium-ion batteries. Electrochim. Acta 2015, 152, 286-293. [CrossRef] 